\title{
PENCIPTAAN SKENARIO FILM TELEVISI “GUNARDI” ADAPTASI KISAH NYATA GUN JACK MENGGUNAKAN SUDUT PANDANG ORANG PERTAMA BUKAN SEBAGAI TOKOH UTAMA
}

\author{
Fanni Mardhotillah \\ Endang Mulyaningsih \\ Agnes Karina Pritha Atmani \\ Jurusan Film \& Televisi, Fakultas Seni Media Rekam, Institut Seni Indonesia Yogyakarta \\ Jl. Parangtritis km. 6.5 Yogyakarta Telp. (0274) 381047
}

\begin{abstract}
ABSTRAK
Banyak media dapat digunakan untuk menceritakan kisah nyata, salah satunya skenario film televisi. Skenario adalah karya dalam bentuk tulisan yang menjadi acuan dalam proses pembuatan film.

Karya tugas akhir penciptaan skenario ini akan berkisah tentang seorang anak perempuan yang mencari tahu identitas ayahnya. Ayah yang ternyata seorang preman dan juga anggota Badan Intelijen Negara.

Memiliki ayah seorang preman terkenal di Yogyakarta pada tahun 2000an menjadi suatu pengalaman menarik sekaligus cobaan berat. Kisah ini dikemas dalam karya tugas akhir yang berjudul Penciptaan Skenario Film Televisi "Gunardi" Adaptasi Kisah Nyata Gun Jack Menggunakan Sudut Pandang Orang Pertama Bukan Sebagai Tokoh Utama. Pendekatan adaptasi yang digunakan yaitu loose atau longgar. Adapasi longgar ini meliputi transfer ide, situasi dan karakter kemudian diubah menjadi skenario "GUNARDI".

Proses penceritaan menggunakan sudut pandang orang pertama bukan sebagai tokoh utama. Tokoh tersebut akan menjadi saksi kisah yang diceritakannya. Penerapan konsep akan digambarkan melalui flashback dan voiceover dalam skenario "GUNARDI"
\end{abstract}

kata kunci: skenario, adaptasi, kisah nyata, sudut pandang

\section{Pendahuluan}

Skenario "GUNARDI" adalah karya Tugas Akhir Skripsi Penciptaan Seni pada ranah penulisan skenario film televisi yang disusun untuk memenuhi syarat kelulusan strata satu Jurusan Televisi, Fakultas Seni Media Rekam, Institut Seni Indonesia Yogyakarta. Skenario "GUNARDI" ini merupakan adaptasi dari kisah nyata Gunardi atau Agus Joko Lukito atau Gowok atau Babe atau lebih dikenal Gun Jack, yakni seorang preman terkenal di Yogyakarta. Karya penulisan skenario film televisi ini menggunakan sudut pandang orang pertama bukan sebagai tokoh utama sebagai cara penyampaian ceritanya. Pembaca atau penonton (jika skenario telah diproduksi menjadi sebuah film televisi), diajak untuk mengenal tokoh utama dari sudut pandang tokoh tambahan atau tokoh pendukung.

Tema tentang kisah preman Jogja menarik apabila diangkat menjadi naskah film televisi. Di dalam naskah ini akan menceritakan kisah Gun Jack dengan anak keduanya, Wulan Mayastika sebagai tokoh utama dari sudut pandang Rudi sebagai sudut pandang orang pertama bukan tokoh utama, yang di dalam cerita merupakan sebagai sahabat Gun Jack. Naskah ini juga akan menceritakan bagaimana Wulan sedari kecil bingung dengan kejadian-kejadian yang dialaminya. Sehingga mencari tahu tentang 
siapa sosok Gun Jack sebenarnya, dan bagaimana Gun Jack menyembunyikan tentang dirinya sebagai seorang anggota BIN (Badan Intelijen Negara) dari orang-orang termasuk anak-anaknya.

Ide ini berawal dari adanya ketertarikan ketika melihat satu program acara televisi (Hitam Putih Trans7) tayang pada tanggal 25 November 2016 pada saat itu mengundang Wulan Mayastika sebagai narasumber untuk menceritakan Gun Jack yang merupakan Ayahnya. Ia menceritakan kisah seorang ayah yang dikenal oleh orang banyak sebagai seorang preman. Pada masa itu ia sering mempertanyakan cara sang ayah mencari nafkah. Kolom keterangan pekerjaan Ayahnya di KTP tertulis sebagai wiraswasta, namun yang ada dalam benaknya saat itu mengapa bapaknya yang merupakan seorang wiraswasta, mempunyai gerombolan anak buah yang selalu siap diperintah. Selain itu, siklus hidup ayahnya terhitung tidak lazim untuk seorang wiraswasta.

Penciptaan skenario "GUNARDI" ini merupakan interpretasi dari kisah nyata Gun Jack. Bentuk kisah nyata Gun Jack berbeda dengan bentuk skenario "GUNARDI". Perbedaan terletak pada alur, meskipun dengan karakter dan garis besar yang sama. Skenario "GUNARDI" menjadi fiksi karena proses penyajian cerita tidak sama persis dengan kisah nyata Gun Jack. Penambahan dan pengurangan akan dilakukan saat menyusun cerita.

Skenario "GUNARDI" ini merupakan penafsiran dari kisah nyata tentang sisi lain dari Gun Jack, seorang preman Yogyakarta yang merupakan anggota BIN. Mengambil ide dan karakter dari sebuah kisah nyata kemudian dijadikan sebuah skenario film televisi, yang menggunakan sudut pandang orang pertama bukan sebagai tokoh utama dalam metode penciptaannya. Adapun karakter- karakter yang ada dikisah nyata dan digunakan dalam skenario adalah Wulan Mayastika dan Gun Jack atau Babe atau Gunardi atau Agus Joko Lukito sebagai tokoh utama yang diceritakan, Dyah Safitri sebagai istri Gun Jack dan Yuda Lukito sebagai anak sulung Gun Jack. Adapun tokoh yang bernama Rudi merupakan tokoh yang sengaja diciptakan sebagai pencerita atau sebagai sudut pandang orang pertama “Aku” tokoh tambahan. Di dalam cerita Rudi merupakan sahabat dari Gun Jack. Tokoh Rudi dipilih sebagai sudut pandang orang pertama sampingan, karena diharapkan dapat memperlihatkan hubungan Gun Jack dan Wulan lebih dekat. Dimana di dalam cerita, Rudilah yang mengetahui kisah keduanya dan menceritakan kepada Bayu yang di dalam cerita sebagai calon suami Wulan. Tokoh Bayu ini juga sengaja diciptakan untuk memperkuat konsep sudut pandang orang pertama bukan sebagai tokoh utama. 
Adaptasi pada umumnya hanya sebuah ide, situasi atau karakter yang diambil dari sumber cerita, kemudian dikembangkan secara mandiri. Krevolin (2003 : 12) menjelaskan bahwa dalam mengadaptasi penulis skenario bebas menceritakan cerita baru yang terinspirasi oleh bahan sumber, sehingga dapat menggabungkan beberapa tokoh, menghapus seluruh bagian, menambah beberapa adegan, mengubah waktu, tanggal, tempat dan melakukan apa saja yang perlu dilakukan untuk kebutuhan membuat skenario.

Dalam proses adaptasi, skenario "GUNARDI" akan menggunakan pendekatan loose (longgar). Dalam hal ini adaptor akan mengambil beberapa ide- ide umum dari sumber cerita kisah nyata Gun Jack, kemudian dikembangkan secara independen. Sehingga skenario "GUNARDI" akan mengambil beberapa cerita kisah nyata Gun Jack yang berpatokan pada hasil riset untuk dibuat jalan cerita atau benang merah sendiri.

Sudut pandang atau point of view dalam karya fiksi mempersoalkan siapa yang menceritakan atau dari posisi tokoh mana peristiwa tersebut diceritakan. Sudut pandang menjadi salah satu unsur fiksi yang digolongkan sebagai sarana cerita. Menurut Fachrudin (2015:203), sudut pandang tersebut bisa melibatkan penulis naskah dalam cerita dan bisa melibatkan dirinya dalam cerita buatannya dengan memosisikan dirinya sebagai salah satu tokoh. Bisa juga tidak melibatkan dirinya dalam cerita buatannya dengan tidak menjadi tokoh. Jadi, sudut pandang merupakan suatu teknik yang digunakan pengarang dalam menampilkan pelaku ceritanya.

Dalam skenario "GUNARDI" sudut pandang orang pertama bukan sebagai tokoh utama, menggunakan flashback dan voice over untuk menceritakan kisah yang diceritakan oleh tokoh sudut pandang orang pertama bukan sebagai tokoh utama tersebut.

\section{Pembahasan}

Pada skenario "GUNARDI" tokoh Rudi merupakan sahabat Gun Jack sejak kecil. Cerita dasar yang digunakan adalah kisah masa lalu Rudi mengenal Gun Jack dari kecil sampai akhirnya meninggal dunia. Kisah tersebut diceritakan kepada Bayu yang merupakan calon suami Wulan saat mereka dalam perjalanan menuju makam Gun Jack. Di dalam cerita, Rudi menjelaskan bagaimana Wulan berusaha untuk mencari tahu identitas ayahnya.

Tokoh yang diciptakan dalam skenario dan juga ada di kisah nyata Gun Jack yakni Gun Jack, Dyah Safitri, Wulan Mayastika, dan Yuda Lukito. Selain tokoh tersebut tokoh-tokoh lainnya merupakan tokoh yang sengaja diciptakan atau bersifat fiktif, begitu juga dengan tokoh Rudi sebagai konsep sudut pandang orang pertama bukan sebagai tokoh utama, dan Bayu sebagai orang yang diceritakan oleh Rudi. Karakter dalam cerita 
akan ada pembagian ditinjau dari tahun cerita yaitu :

a. Gun Jack kecil (12 tahun), untuk cerita tahun 1980

b. Gun Jack remaja ( 15 \& 17 tahun), untuk cerita tahun $1983 \& 1985$

c. Gun Jack muda (20-24 tahun), untuk cerita tahun $1988,1989 \& 1991$

d. Gun Jack (34 \& 37 tahun), Wulan kecil (8 \& 11 tahun), untuk cerita tahun $2002 \& 2005$

e. Gun Jack (41 \& 42 tahun), Wulan remaja (15 \& 16 tahun), untuk cerita tahun $2009 \& 2010$

f. Wulan (23 tahun), Rudi tua (51 tahun) untuk cerita tahun 2017

Plot atau alur dalam skenario "GUNARDI" menggunakan alur non-linear dengan menggunakan flashback untuk menceritakan kejadian masa lalu serta menunjukkan cerita tersebut disajikan dengan menggunakan sudut pandang orang pertama bukan sebagai tokoh utama.

Cerita kejadian masa lalu akan tetap tersusun menjadi satu alur cerita linier yang bergerak maju. Kejadian pada masa lalu yang diceritakan memiliki andil besar dalam skenario, karena konflik ada pada kejadian masa lalu. Selain itu kejadian masa lalu digunakan sebagai konfirmasi atas kejadian yang terjadi pada saat ini.

Tahapan setting dalam cerita ada dua, yaitu setting waktu dan setting lokasi.
Setting waktu pada skenario "GUNARDI" terbagi menjadi:

a. Tahun 1980, Gun Jack berumur 12 tahun.

b. Tahun 1983, Gun Jack berumur 15 tahun.

c. Tahun 1985, Gun Jack berumur 17 tahun.

d. Tahun 1988, Gun Jack berumur 20 tahun.

e. Tahun 1989, Gun jack berumur 21 tahun.

f. Tahun 1991, Gun Jack berumur 23 tahun.

g. Tahun 1994, Wulan lahir.

h. Tahun 2002, Gun Jack berumur 34 tahun, Wulan berumur 8 tahun.

i. Tahun 2005, Gun Jack berumur 37 tahun, Wulan berumur 11 tahun.

j. Tahun 2010, Gun Jack berumur 42 tahun, Wulan berumur 16 tahun.

k. Tahun 2017 Wulan berumur 23 tahun.

Berdasarkan susunan cerita, masingmasing tahun tersebut perlu diketahui karena berhubungan langsung dengan artistik serta perubahan karakter secara fisik. Dalam memperlihatkan tahun cerita di dalam skenario, keterangan tahun akan ditulis pada bagian scene heading dan neben text yang menjelaskan bahwa di dalam film (jika sudah diproduksi) akan ditulis keterangan tahun dengan menggunakan tulisan. Contohnya, “Tahun 1980".

\section{Adaptasi Kisah Nyata}

Adaptasi dari kisah nyata ke dalam sebuah skenario melakukan beberapa perubahan dengan mengacu kepada konsep adaptasi. Bentuk tersebut adalah menambahkan beberapa tokoh, menghapus 
seluruh bagian, menambah beberapa adegan, mengubah waktu, tanggal, dan tempat. Terdapat 32 scene dari 105 scene (30\%) untuk menerapkan kisah nyata cerita Gun Jack ke dalam skenario "GUNARDI". Namun terdapat beberapa scene lain yang dibuat dengan sengaja dan berpatokan pada cerita kisah nyata Gun Jack. Terdapat 32 scene dari 105 scene (30\%) untuk menerapkan kisah nyata cerita Gun Jack ke dalam skenario "GUNARDI". Namun terdapat beberapa scene lain yang dibuat dengan sengaja dan berpatokan pada cerita kisah nyata Gun Jack.

Penerapan cerita dari kisah nyata ke dalam bentuk naskah skenario salah satunya adalah cerita tentang Gun Jack merupakan seorang ayah yang berbeda dengan ayah pada umumnya. Faktanya Gun Jack tidak pernah tau tentang perkembangan sekolah anaknya, terutama Wulan. Bahkan Gun Jack tidak pernah menandatangani rapot sekolah anakanaknya. Cerita tersebut digambarkan dalam scene 20, adegan Wulan yang menunggu Gun Jack pulang ke rumah agar dapat menandatangani rapot miliknya. Dalam scene ini juga memperlihatkan Gun Jack yang jarang pulang ke rumah dan Wulan protes dengan hal tersebut. Serta scene 61 adegan Gun Jack tidak tahu kalau ternyata Wulan sudah libur sekolah.

Transkrip wawancara Dyah:

... tanda tangan dirapot itu gak ada tanda tangan dia (Gun Jack). Pas yang kemarin itu aja sebelum dia meninggal. Wulan SMA kan minta babenya terus......

Transkrip wawancara Wulan:

... Orang anaknya sekolah di mana aja dia (Gun Jack) gak tahu. Aku uda libur terima rapot aja Babe gak tau

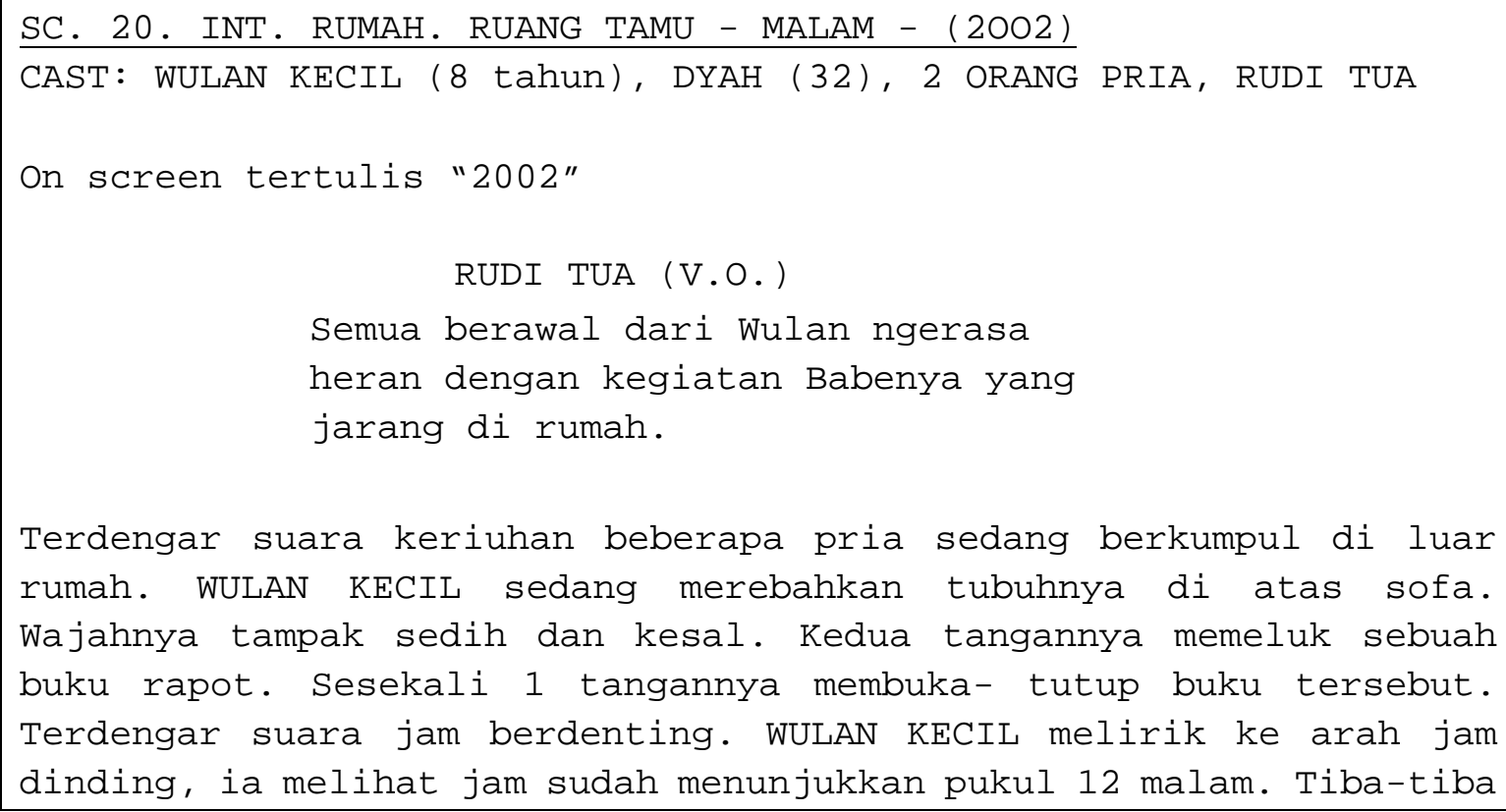


DYAH keluar dari kamar sambil mengikat rambutnya, ia terlihat baru bangun tidur.

\section{DYAH}

Loh, Nduk kok belum bobok? (terkejut

dan menghampiri Wulan)

\section{WULAN KECIL}

Babe kok belum pulang Buk?

DYAH

Gak usah nunggu Babe, bobok aja.

WULAN KECIL

Mau minta tanda tangan Babe buat

rapot, besok dikumpulin.

\section{DYAH}

Owalah, yauda sini, ibu tanda

tanganin aja.

\section{WULAN KECIL}

Babe aja ah Buk. Biar sekalian Babe

liat nilaiku bagus-bagus.

\section{DYAH}

Babe gak pulang, uda sini Ibuk aja yang tanda tangan. (mengambil paksa rapot dari Wulankemudian diletakkan di atas meja) Uda bobok aja, biar besok gak kesiangan. (merubah posisi Wulan menjadi duduk)

\section{WULAN KECIL}

Ih, ibukk... (manja) Babe tuh sering banget nggak pulang, ngapain si

Babe? (beranjak)

WULAN KECIL berjalan ke arah kamarnya, DYAH menarik nafas sambil tersenyum kecil, kemudian menandatangani rapot WULAN. Beranjak dari tempatnya, berjalan ke arah jendela dan mengintip ke luar rumah, DYAH melihat 2 ORANG PRIA MABUK sedang berjalan di gang rumahnya, keduanya terlihat mabuk dan membawa botol minuman. 





Penerapan kisah nyata lainnya adalah saat Wulan menemukan beberapa senjata tajam di dalam mobil yang digunakan Dyah untuk mengantar Wulan ke sekolah. Wulan merasa ada yang aneh saat ia menemukan beberapa senjata tajam tersebut dan membuat ia bertanya-tanya apa sebenarnya yang terjadi. Hal tersebut digambarkan dalam adegan sama, hanya saja ada pengembangan alasan Wulan tiba-tiba dapat menemukan sejata tajam dikarenakan tanpa sengaja rapot miliknya jatuh dari dashboard mobil sehingga saat ia mengambil rapotnya ia melihat ada beberapa senjata tajam. Scene 23 ini juga merupakan lanjutan dari scene 20 saat Wulan ingin meminta tanda tangan Gun Jack. Letak posisi duduk Wulan juga berbeda, karena di dalam cerita yang mengantar Wulan ke sekolah adalah Dyah, sehingga memperlihatkan hubungan kedekatan Wulan dan Dyah, di dalam naskah Wulan duduk di bagian depan mobil.

Transkrip wawancara Wulan:

... Trus paginya aku dianter sekolah. Trus aku duduk dibelakang kan. Nah dibawah itu trus lah kok ada kayak samurai. "ini punya siapa bu?" "oh itu punya Babe ketinggalan".




WULAN KECIL mengerutkan dahinya, ia kembali pada posisi duduk. Kemudian ia meletakkan buku rapot di atas pahanya, dan kembali WULAN KECIL duduk sambil bersandar pada kaca mobil, kali ini wajahnya terlihat sedang memikirkan sesuatu. Sesampainya di depan sekolah, WULAN KECIL bersalaman dengan DYAH, kemudian membuka pintu mobil dan bersiap untuk turun dari mobil.

CUT TO:

Wulan semakin merasa bertanya-tanya saat adanya serangan dari musuh Gun Jack terhadap rumahnya. Hal tersebut diwujudkan dalam scene 28-36, adegan tambahan yang dibuat yaitu saat musuhnya Gun Jack bersiap untuk menyerang rumah dan dibarengin dengan adegan Wulan dan Yuda tengah belajar di ruang tamu sambil ditemani oleh Dyah. Adegan selanjutnya berkesinambungan dengan scene 41 , saat Gun Jack yang pulang dari luar kota mencoba untuk menenangkan Wulan, namun Wulan bertanya-tanya tentang apa sebenarnya yang terjadi.

Transkrip wawancara Wulan:

... Dulu waktu aku dua atau tiga tahun di rumahku yang di pinggir jalan bukan di sini. Tengah malem banyak orang dateng. Aku pikir teman Babe, tau-tau ngeluarin samurai dan dipecahkan semua kaca rumah. Trus aku, ibu dan kakakku dibawa masuk ke dalam. Semua tetangga juga takut. Ada sekitar dua mobil gitu. Itu pertama kali aku lihat musuhnya Babe. Sejak itu aku selalu mikir ini bapakku kenapa sih sampai ada orang sampai segitunya. Babe cuma bilang itu orang iseng. Aku taunya baru sekarang-sekarang tu dulu zamannya PPP, PDI yang ada premannya sampai sekarang sih. Temen-temen Babe yang masih di jalan konfliknya sama orang PDI.



WULAN KECIL, YUDA KECIL, dan DYAH mendengar kegaduhan tersebut, ketiganya beranjak dari tempat duduk. DYAH mengintip dari jendela, begitu juga dengan WULAN KECIL dan YUDA KECIL yang mengintip dari sisi kiri jendela. WULAN KECIL melihat di luar rumah sudah rame orang, ada 8 ANGGOTA PBI yang bersiap menyerang rumah mereka, 4 masih berada di atas motor karena motor masih dalam keadaan hidup 
sehingga suara semakin terasa gaduh. PARA TETANGGA terlihat ketakutan dan berlarian masuk ke dalam rumah. Dari jendela terlihat tiba-tiba seorang mengeluarkan sebuah pedang katana. DYAH langsung menarik WULAN KECIL dan YUDA KECIL dan berlari ke arah dapur.

INTERCUT WITH :

SC. 36. INT. RUMAH. DAPUR - MALAM - (2002)

CAST: DYAH, WULAN KECIL, YUDA KECIL, RUDI, RUDI TUA

Terdengar suara motor pergi menjauh dari rumah. DYAH memegang erat WULAN KECIL dan YUDA KECIL, mereka bersembunyi di bawah meja. Samarsamar terlihat asap dari arah ruang tamu. WULAN KECIL terlihat ketakutan. Ia memegang erat tangan DYAH. RUDI masuk ke dapur melewati asap yang mengepul. Wajahnya terlihat khawatir, kemudian ia melihat WULAN KECIL, YUDA KECIL dan DYAH di bawah meja.

$$
\begin{aligned}
& \text { RUDI TUA (V.O.) } \\
& \text { Dan saat itu, Wulan semakin } \\
& \text { bertanya-tanya tentang siapa } \\
& \text { sebenarnya Babenya? Kenapa orang- } \\
& \text { orang tadi menyerang rumahnya. }
\end{aligned}
$$

SHOT: RUDI MELIHAT WULAN KETAKUTAN.

CUT TO:

SC. 41. INT. RUMAH. DAPUR - PAGI - (2002)

CAST: WULAN KECIL, RUDI, GUN JACK

Terdengar samar-samar suara TV dari ruang tamu. WULAN KECIL sedang menikmati tiwul. GUN JACK datang menghampiri, wajah WULAN KECIL tampak kesal.

\section{GUN JACK}

Mbak Wulan kok gak sekolah?

WULAN KECIL hanya diam, ia hanya melirik sinis ke arah GUN JACK. RUDI berjalan mengambil segelas air minum.

GUN JACK (CONT'D)

(duduk di sebelah Wulan)

Mbak Wulan ambilin Babe maem.

WULAN KECIL

(melirik sinis ke arah Gun Jack)

Babe dari mana sih? 


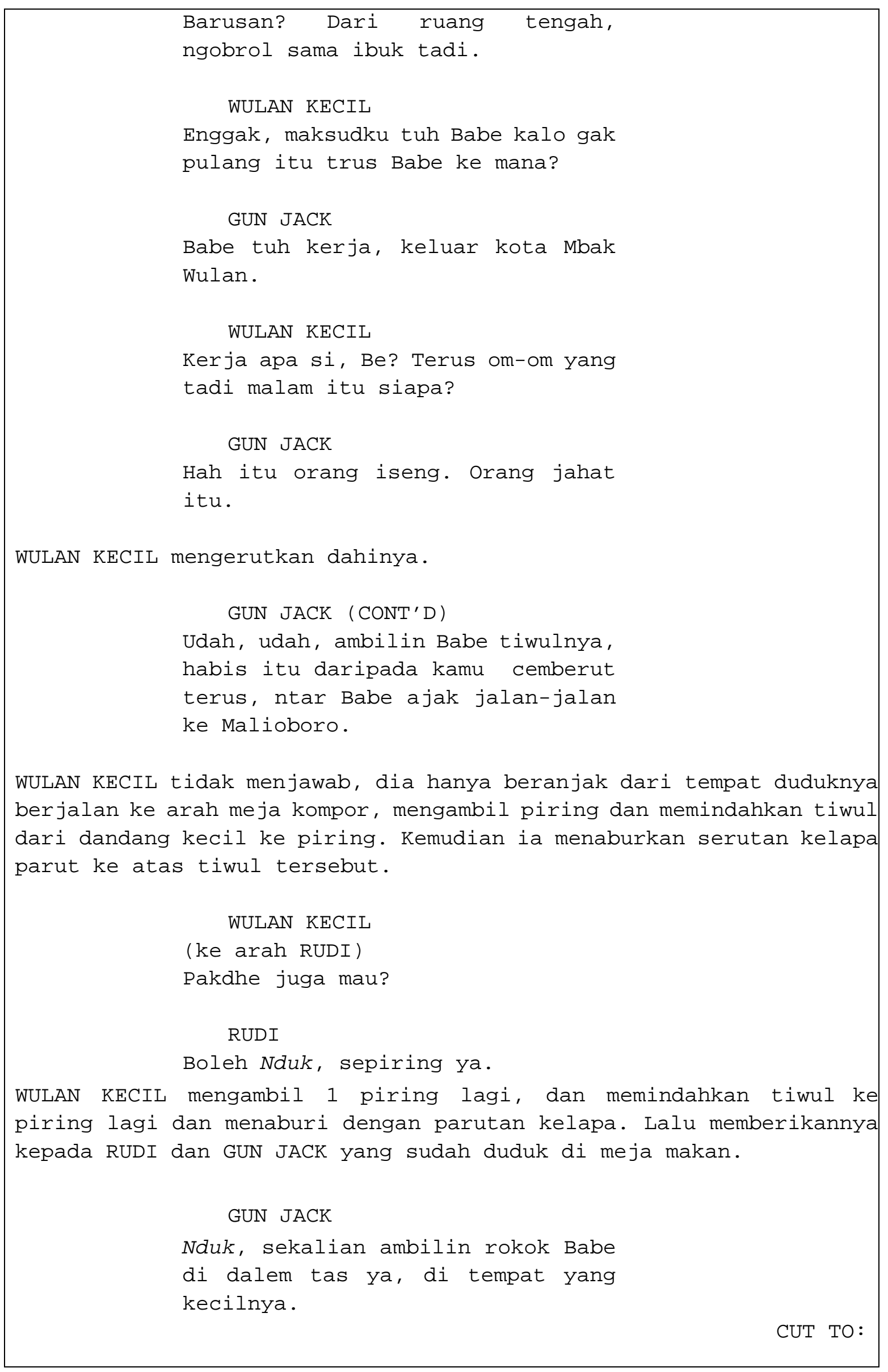


Wulan mengetahui Gun Jack adalah anggota BIN dari Gun Jack yang langsung memberi tahu kepada Wulan. Hal itu dilakukan Gun Jack karena Wulan sempat membenci Gun Jack dan tidak berkomunikasi dengan Gun Jack dalam waktu yang cukup lama. Dalam naskah, adegan tersebut akan diganti dengan Wulan mengetahui Gun Jack anggota BIN dari Rudi, saat 7 tahun setelah Gun Jack meninggal dunia dan Wulan akan menikah dengan Bayu. Adegan tersebut diwujudkan pada scene 102-105.

\section{Transkrip wawancara Wulan:}

Jadi dulu Babe tuh karena aku sering ngambek kan, terus aku pernah marah banget sama Babe, dan ngambeknya lama, terus akhirnya Babe ngajak aku untuk ngobrol berdua, terus dia nunjukin kartu identitas keanggotaan BIN, terus Babe bilang Babe maunya kamu bangga punya orang tua kaya Babe........

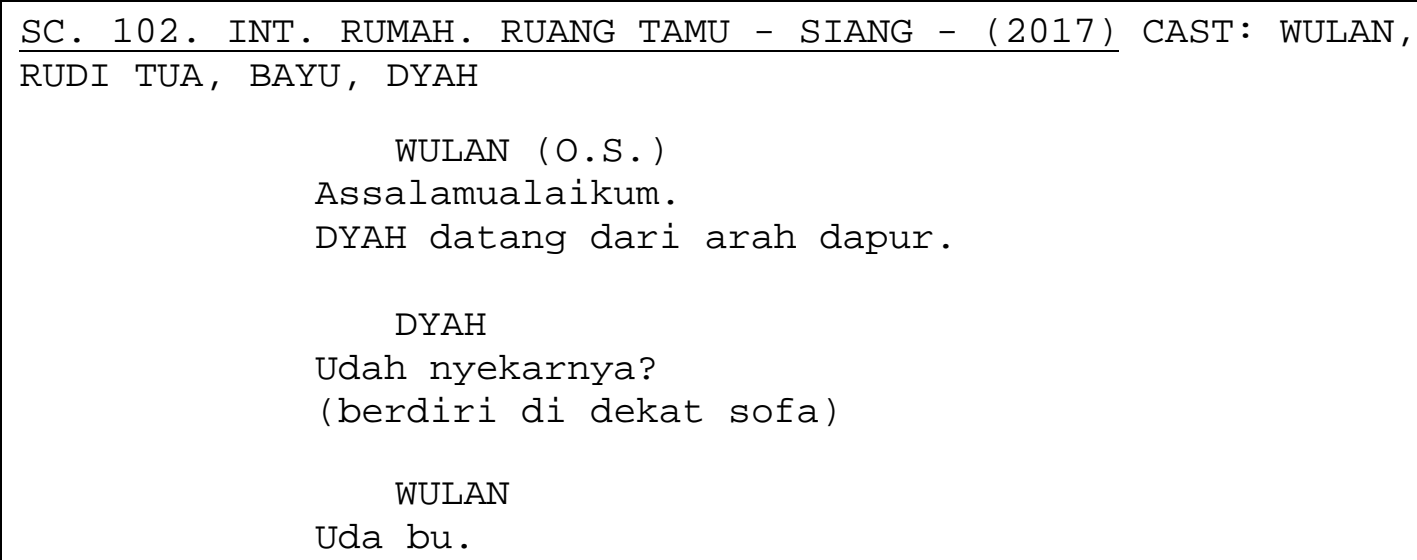

WULAN masuk ke dalam rumah sambil memegangi RUDI TUA yang kemudian duduk di sofa tamu, BAYU masuk ke dalam rumah dan kemudian ikut duduk.




BAYU. RUDI tua memberikan koper kecil berwarna coklat tersebut ke pada WULAN.

WULAN (CONT'D)

Apa ini pakdhe? Bukannya ini tas

Babe?

RUDI TUA

Bukalah. Kodenya tanggal lahir

kamu .

WULAN meletakkan koper tersebut di atas pahanya dan kemudian mengatur sandi koper, tak berapa lama koper pun terbuka. Wajah WULAN tampak bingung melihat isi dari koper tersebut, dilihatnya satu persatu isi dari koper tersebut, terdapat sebuah surat di dalamnya, WULAN membaca surat tersebut, dan tiba-tiba matanya berkaca dan air matapun menetes di surat tersebut.

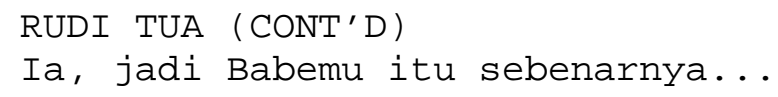

DISSOLVE TO:

SC. 103. BEGIN FLASHBACK (CONTINUITY SC. 8) - EXT. JALAN

RAYA DEPAN LAPAS - SIANG - (1985)

CAST: GUN JACK REMAJA, 2 PRIA

2 PRIA bertubuh besar memakai baju berwarna hitam memasukkan tubuh GUN JACK REMAJA yang sedang membungkukkan tubuhnya ke dalam karung coklat berukuran besar. GUN JACK meronta-ronta, namun 2 PRIA lebih kuat darinya dan berhasil memasukkan GUN JACK ke dalam karung.

CUT TO:

SC. 104. END FLASHBCAK - INT. RUANG GELAP - SIANG - (1985)

CAST: GUN JACK, RUDI (19 tahun), KOMANDAN KOPASUS, PRIA BERTUBUH BESAR 1

Sebuah lampu baru saja dihidupkan dan menyoroti GUN JACK yang duduk di sebuah kursi, di depannya terdapat sebuah meja. PRIA BERTUBUH BESAR 1 membukakan kain penutup mata GUN JACK, pandangan GUN JACK masih samar-samar melihat ke sekitar ruangan, ia terlihat bingung, di sana dia melihat RUDI berdiri sambil memperhatikan dirinya. Wajah GUN JACK bingung, ia mengerutkan dahinya. Seorang KOMANDAN KOPASUS yang menggunakan seragam lengkap TNI berdiri di depan GUN JACK dan sedang menjelaskan sesuatu kepada GUN JACK. GUN JACK terlihat bingung dan berfikir.

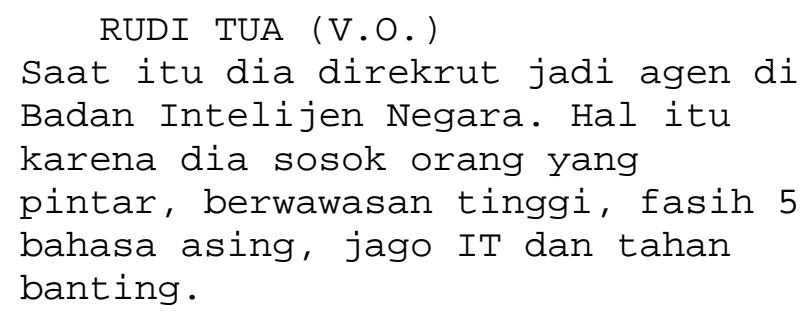

KOMANDAN KOPASUS menyodorkan sebuah berkas ke atas meja lengkap dengan sebuah pulpen. GUN JACK tampak berfikir sejenak, kemudian dia menandatangani sebuah form di kertas tersebut.

RUDI TUA (V.O.) 


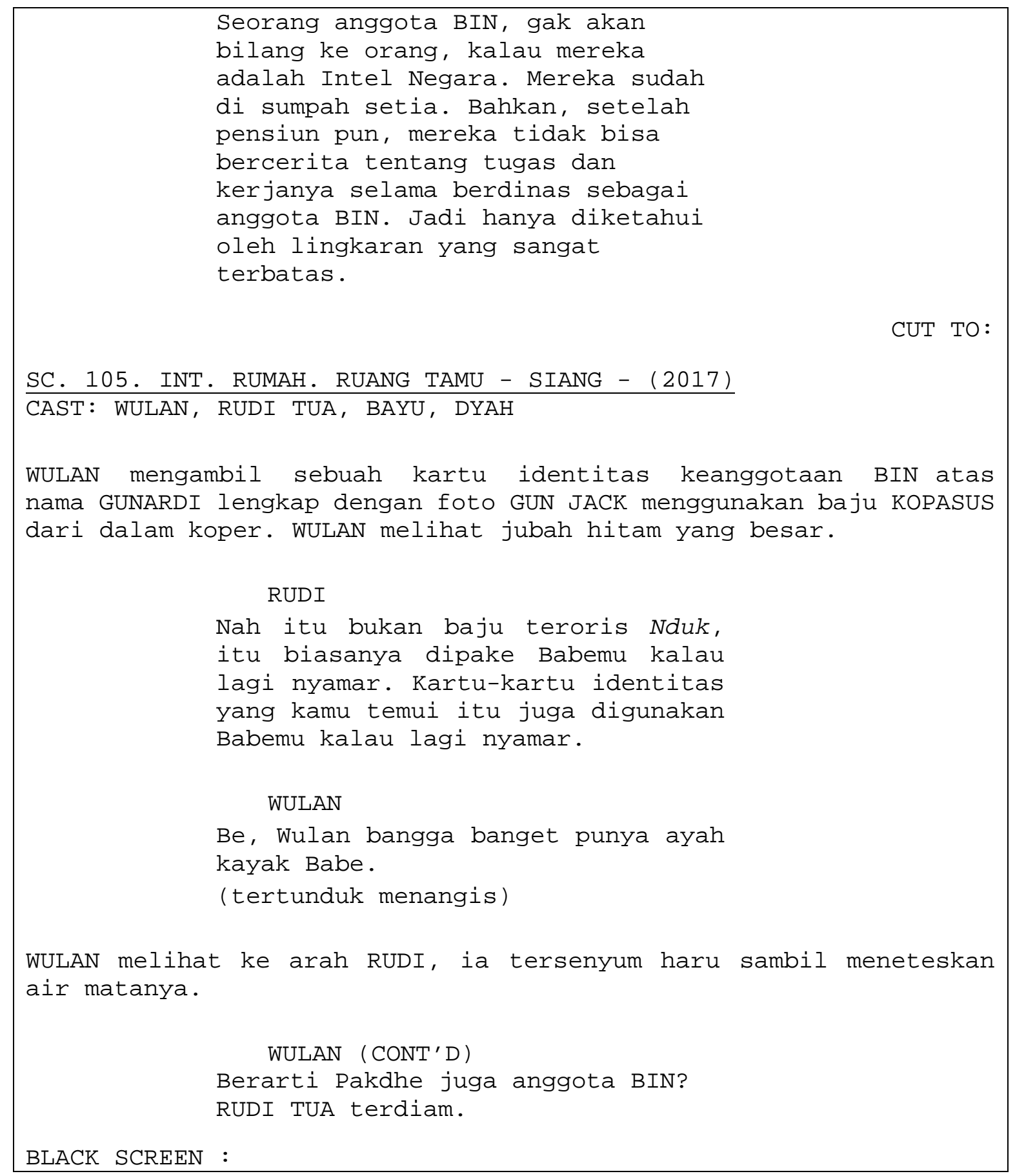

2. Penerapan Sudut Pandang Orang scene $1,2,3,4,5,6,7,9,10,11,13,14,15$, Pertama Bukan Sebagai Tokoh Utama $16,18,19,20,24,27,36,37,39,40,41,42$,

Tokoh Rudi merupakan tokoh yang diciptakan untuk menerapkan sudut pandang orang pertama bukan sebagai tokoh utama. Penerapan tersebut tampak di 63 scene dari $43,44,45,46,47,48,49,51,55,56,58,59$, $60,62,63,64,65,72,73,76,77,79,80,84$, 90, 92, 93, 94, 95, 96, 97, 98, 99, 100, 101, 102, 104, dan 105. Dalam cerita tokoh Rudi menjadi penting untuk menjadi sudut total 105 scene (60\%) yakni diterapkan pada pandang orang pertama bukan sebagai tokoh utama, karena di dalam cerita Rudi bercerita 
kepada Bayu yang merupakan calon suami Wulan, selama perjalanan menuju ke makam Gun Jack. Hampir di seluruh scene, tokoh Rudi akan selalu ada, baik itu sebagai pencerita (voice over) ataupun saksi.

Penerapan sudut pandang orang pertama bukan sebagai tokoh utama ini diwujudkan dengan flashback dan penggunaan voiceover. Penerapan scene flashback ada pada scene 1, 3, 48, 61, 100 dan 103. Jika scene flashback hanya terdiri dari satu adegan saja maka akan ditulis "(FLASHBACK)" pada scene heading. Hal tersebut diterapkan pada scene 1 dan 100 . Penjelasan tersebut ditandai dalam huruf tebal. Pada scene 1 juga terdapat voice over dari Rudi untuk memperkenalkan hubungannya dengan Gun Jack, bahwa mereka saling kenal sejak kecil. Selain itu penjelasan shot yang akan diambil saat dialog Rudi menyebutkan "aku" diberi keterangan shot gambar Rudi sebagai pencerita, dan saat menyebutkan "dia, Agus Joko Lukito" diberi keterangan shot yang diambil adalah Gun Jack.

SC. 1. INT. STASIUN TUGU YOGYAKARTA - SIANG - (1980)
(FLASHBACK)
CAST: GUN JACK KECIL (12 tahun), RUDI KECIL (14 tahun), PETUGAS
STASIUN, OPERATOR STASIUN, BEBERAPA ORANG PENGUNJUNG STASIUN, RUDI
TUA
On screen tertulis "1980"
Suasana stasiun ramai, BEBERAPA ORANG PENGUNJUNG STASIUN sibuk
dengan kegiatannya, ada yang sedang menunggu di kursi tunggu, ada
yang sedang masuk ke dalam kereta, ada juga beberapa pedagang
asongan yang menjajakan dagangannya. Di pinggiran rel, terlihat
dari belakang seorang anak laki- laki sedang berdiri sambil membawa
keranjang yang berisikan nasi bungkus yang dibungkus kertas koran.
Tidak lama sebuah kereta tiba, RUDI KECIL langsung naik ke dalam
salah satu gerbong kereta. Terlihat dari belakang ia berjalan di
tengah gerbong kereta dari gerbong satu ke gerbong lainnya sambil
menjajakan dagangannya, beberapa penumpang membeli dagangannya.
Terdengar suara lonceng dan suara kereta datang. Terlihat seorang
PETUGAS STASIUN memberikan informasi kepada para penumpang.
PETUGAS STASIUN
Rara penumpang siap-siap, kereta
jalur pertama ke arah utara menuju
Magelang dan berakhir di Parakan
anak laki-laki memakai celana SMP berwarna biru berlari ke arah
RUDI KECIL dan langsung mendorong hingga terjatuh.
(Berulang-ulang)




\section{GUN JACK KECIL \\ Iki wilayahku! \\ (Ini wilayahku!)}

GUN JACK KECIL memukuli wajah RUDI KECIL. RUDI KECIL berusaha untuk melindungi wajahnya dengan dua tangan namun gerakan GUN JACK KECIL sangat cepat sehingga beberapa kali tonjokan GUN JACK KECIL mengenai pipi RUDI KECIL. Tiba-tiba dari kejauhan terdengar suara peluit PETUGAS STASIUN yang ingin melerai keduanya. GUN JACK KECIL melihat ke arah sumber suara.

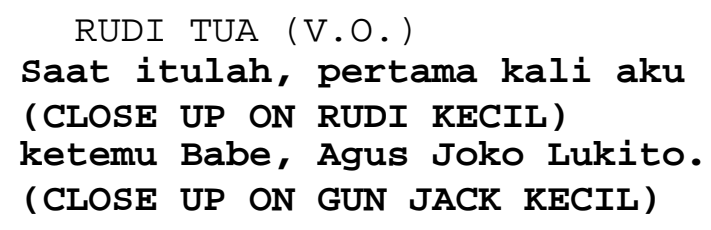

Penggunaan voice over Rudi sebagai tokoh pencerita juga diwujudkan dalam scene lainnya, yaitu scene 1, 3, 4, 5, 6, 7, 9, $10,11,13,14,15,16,18,19,20,27,36,38$, 55, 96, 100, dan 104. Salah satu tujuan dari adanya penggunaan voice over yakni digunakan untuk menyampaikan informasi latar belakang cerita yang tidak dapat dijelaskan dalam bentuk visual saja. Hal itu diterapkan dalam beberapa scene salah satunya ada pada scene 27. Voice over menjelaskan bahwa saat itu adalah pertama kali Wulan bertanya ke pada Rudi tentang pekerjaan Gun Jack yang sebenarnya yang tidak dapat dijelaskan hanya dengan visual saja.

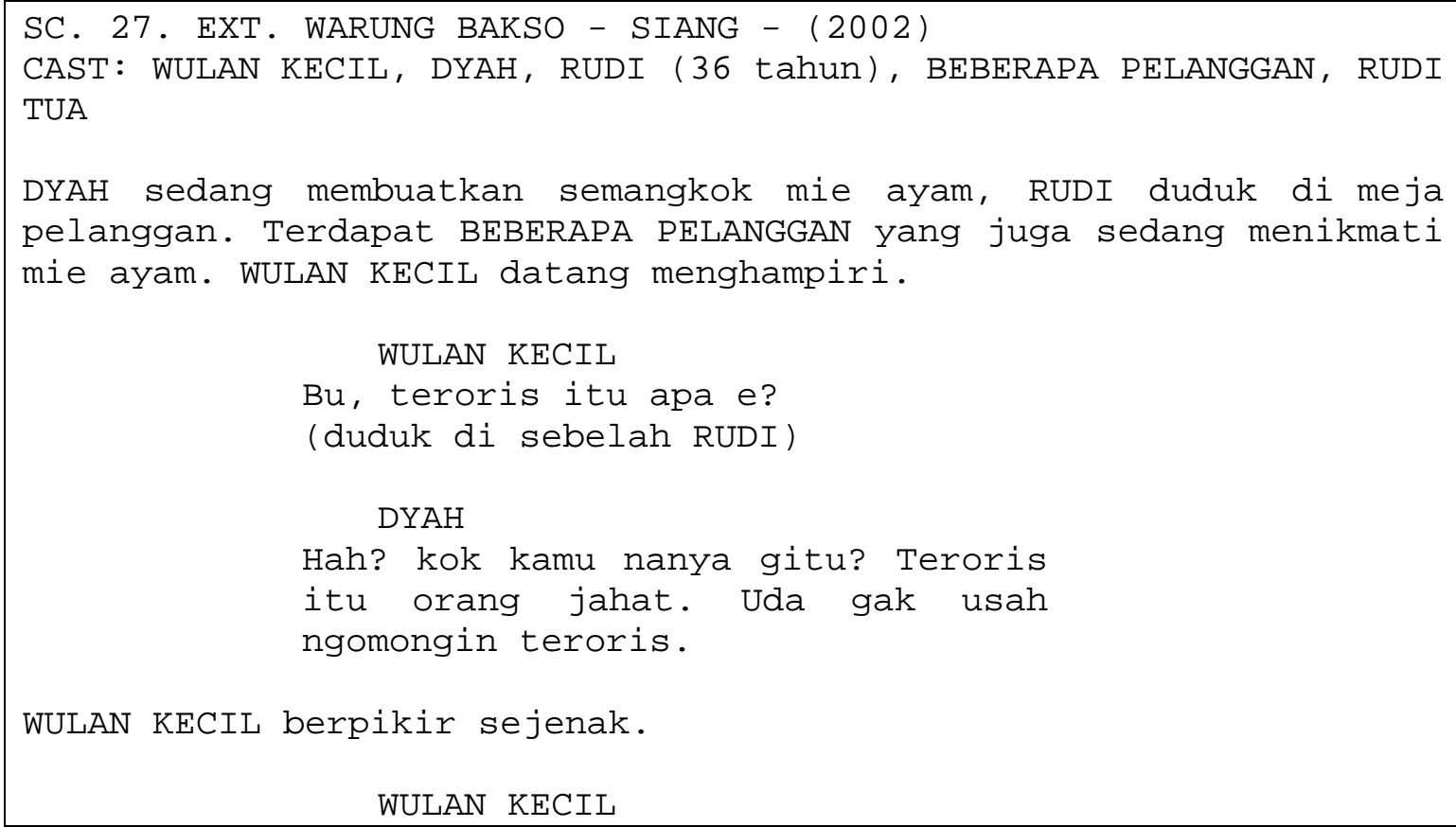




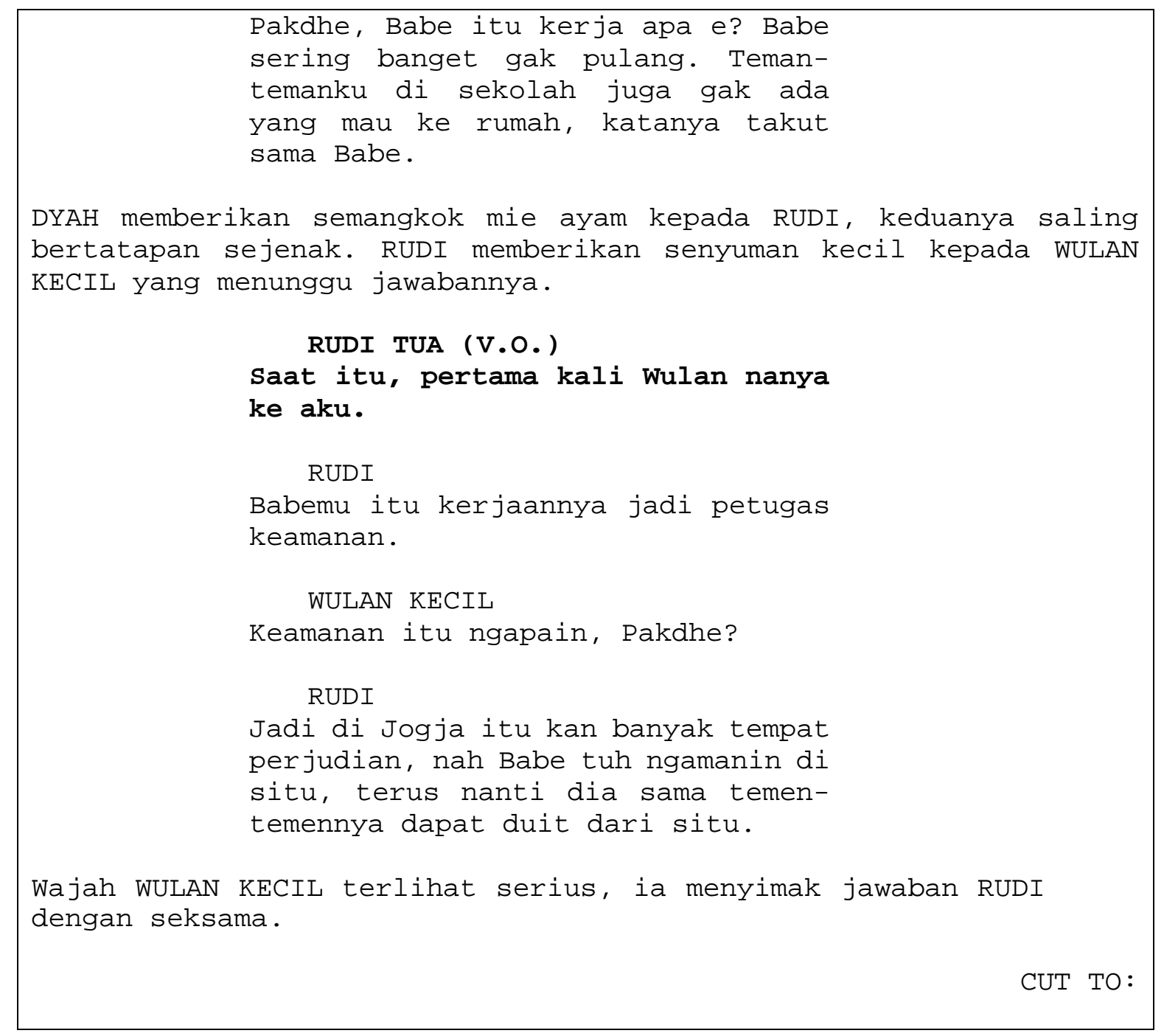

Voice over juga digunakan untuk membuat kesinambungan cerita, hal tersebut salah satunya diperlihatkan pada awal cerita yaitu pada scene 1-20. Voice over digunakan untuk memperkenalkan sosok Gun Jack dari kecil, sampai menikah kemudian memiliki anak yang merasa heran dengan sosok Gun Jack.

Voice over sebagai transisi dari masa sekarang ke masa lalu juga diterapkan dalam skenario, salah satunya pada scene 102-104. Dialog pada voice over menjelaskan bahwa Gun Jack sebenarnya adalah anggota BIN.
Voice over sebagai pengantar Rudi menceritakan yang telah terjadi di masa lalu.

Scene 100 juga merupakan flashback dengan 1 adegan yang menjelaskan bahwa tokoh Gun Jack meninggal pada tahun 2010. Pada scene ini juga menggunakan voice over untuk menambah informasi yang diketahui oleh Rudi. Untuk menunjukkan bahwa ini merupakan dari sudut pandang Rudi, juga terdapat adegan Rudi melihat dan memperhatikan Wulan. Voice over dari Rudi juga merupakan penilaian Rudi terhadap tokoh yang sedang ia ceritakan. 
SC. 100. EXT. DEPAN RUMAH - SIANG - (2010) (FLASHBACK)

CAST: WULAN REMAJA, RUDI, DYAH, YUDA, TEMAN GUN JACK 1, TEMAN GUN JACK 2, TEMAN GUN JACK 3, TEMAN GUN JACK 4, PARA ANGGOTA PSP, PARA TETANGGA, CALO 1, PARA ANAK JALANAN

On screen tertulis "2010"

Suasana agak ramai, terlihat beberapa karangan bunga dari berbagai instansi mengucapkan "turut berbelasungkawa atas meninggalnya Agus Joko Lukito". Tenda biru terpasang di depan rumah. Beberapa kursi tersusun di kanan kiri jalan, terlihat di sana ada PARA ANGGOTA PSP yang memakai kemeja hijau duduk sambil saling berbincang dengan suara yang cukup pelan, CALO 1 juga terlihat duduk bersama TEMAN GUN JACK 1, TEMAN GUN JACK 2, TEMAN GUN JACK 3, TEMAN GUN JACK 4 menyusun kursi-kursi yang kosong. PARA TETANGGA berlalu lalang, mereka ada memakai baju koko, sarung, dan ada pula yang memakai kopiah. 3 PSK menggunakan pakaian ketat dan menutupi kepalanya hanya dengan selendang duduk di kursi, ketiganya tampak sedih. YUDA REMAJA dan RUDI duduk di depan rumah, beberapa orang silih berganti berjabat tangan dengannya, kemudian pergi. WULAN REMAJA dan DYAH datang dan duduk di sebelah YUDA REMAJA dan RUDI, keduanya memakai pakaian berwarna hitam. Hidung DYAH merah, matanya sembab sesekali ia mengeringkan hidungnya dengan tisu yang dipegangnya.

\section{DYAH}

Ibu gak nyangka banyak orang yang nyolatin Babe tadi, banyak orang yang dateng ke pemakaman Babe.

Tiba-tiba CALO 1 mendatangi DYAH.

\section{CALO 1}

$\mathrm{Bu}$, kulo nderek bela sungkawa nggih, Amergi almarhum, bekas narapidana koyo kulo saget nyambut damel. Sekalian kulo pamit nggih $\mathrm{Bu}$.

(Bu, saya turut berduka cita yah, karena almarhum, mantan narapidana kaya saya bisa kerja. Sekalian saya mau pamit.)

WULAN REMAJA terkejut mendengar ucapan CALO 1. YUDA REMAJA merangkul DYAH, sedangkan RUDI, ia hanya menunduk.

\section{DYAH}

Nggih mas, nyuwonke ngapunten misal Babe wonten lepatipun. 


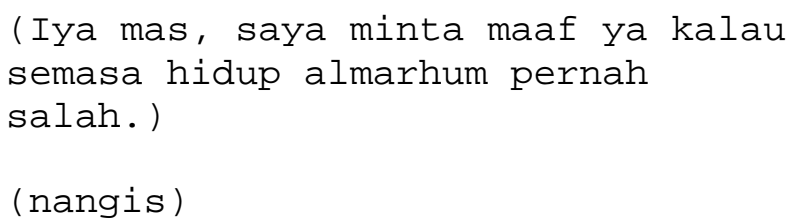

CALO 1 bersalaman dengan DYAH, YUDA REMAJA, WULAN REMAJA, dan RUDI. DYAH menangis haru mendengar pengakuan CALO 1 . CALO 1 pun kemudian pergi.

WULAN REMAJA mengerutkan dahinya, seolah ia sedang memikirkan sesuatu. RUDI memperhatikan WULAN REMAJA.

$$
\text { RUDI TUA (V.O.) }
$$

Wulan perlahan dapat informasi dari orang-orang bahwa ternyata Babenya orang yang sangat baik.

Gun Jack merangkul para narapidana yang sudah bebas dan diberi pekerjaan.

3 PSK beranjak dari duduknya kemudian mendatangi DYAH satu persatu dari mereka memeluk DYAH. WULAN REMAJA memperhatikan 3 PSK dan DYAH, wajahnya terlihat menahan tangis, matanya berkaca-kaca.

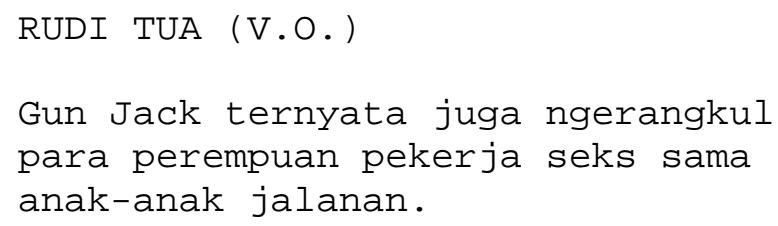

RUDI memperhatikan WULAN REMAJA, WULAN REMAJA melihat ke arah kumpulan PARA ANAK JALANAN yang duduk tidak jauh dari WULAN REMAJA duduk, mereka tertunduk terlihat sedih. WULAN REMAJA mendekati PARA ANAK JALANAN.

\section{WULAN REMAJA}

Dek, kalian ngapain di sini?

ANAK JALANAN 1

Kita sedih Babe ninggalin kita mbak .

\section{WULAN REMAJA}

Kalian ini siapanya Babe?

\section{ANAK JALANAN 1}

Kita ini anak asuhnya Babe, Karena Babe kami bisa sekolah, mbak. Bisa belajar sama punya tempat tinggal. 




\section{Kesimpulan}

Proses adaptasi bukanlah hal asing dalam dunia penciptaan karya, termasuk dalam pembuatan skenario film. Adaptasi dari kisah nyata kemudian dikemas dengan sudut pandang orang pertama bukan sebagai tokoh utama bisa menjadi satu hal baru dalam membuat skenario. Skenario dengan sudut pandang orang pertama bukan sebagai tokoh utama ini mencoba menceritakan kembali kisah seorang preman atau gali terkenal di Yogyakarta. Kisah terfokus pada persoalan anak bungsunya yang sedari kecil bertanya dan mencari tahu identitas ayahnya yang ternyata adalah seorang preman dan juga anggota BIN. Pembuatan cerita dari proses menentukan premis, menentukan tokoh, setting lokasi dan waktu, maupun pembentukan adegan dan dialog melalui proses yang tidak mudah.

Penciptaan skenario dari cerita kisah nyata perlu mempertimbangkan beberapa hal, misalnya memilih dan menentukan cerita mana saja yang akan diterapkan ke dalam naskah dari hasil riset. Hasil riset yang banyak dan beragam juga dibutuhkan pertimbangan yang matang, dalam hal ini harus berpatokan pada premis yang sudah dibuat. Menambah ataupun mengganti nama tokoh atau instansi yang ada di dalam cerita nyata ke dalam skenario juga memerlukan pertimbangan yang matang. Selain itu, alur dari cerita kisah nyata akan mengalami perubahan setelah dibentuk sebuah treatment.

Dalam proses adaptasi kisah nyata Gun Jack menjadi skenario "GUNARDI" terdapat banyak cerita yang belum pernah di publish sebelumnya dan belum diketahui oleh masyarakat luas. Sehingga bentuk cerita dalam skenario menjadi sebuah cerita baru yang menarik untuk dibaca.

Penggunaan sudut pandang orang pertama bukan sebagai tokoh utama juga menjadikan skenario adaptasi dari kisah nyata ini menjadi sebuah cerita yang "dirasa" benar-benar seperti kisah nyata benar terjadi karena ada sosok tokoh yang menjadi saksi jalannya cerita untuk menceritakan kisah tentang tokoh utama. 


\section{Daftar Pustaka}

Gianetti, Louis. Understanding Movies;

9th edition. New Jersey: Prentice

Hall: 2001

Krevolin, Richard. How to Adaptation

Anything into a Screenplay. Bandung:

PT.Mizan Pustaka. 2003.

Fachruddin, Andi. Cara Kreatif

Memproduksi Program Televisi.

Yogyakarta: CV. Andi Offset. 2015.

\section{Sumber Wawancara}

Wulan Mayastika - Anak bungsu dari Gun

Jack (Januari, 2017)

Dyah Safitri - Istri Gun Jack (Januari, 2017)

Andriana - Anak dari salah satu anggota

BIN (Desember, 2017) 